\title{
A STUDY ON ACADEMIC ENGAGEMENT OF COLLEGE GOING STUDENTS DURING NATIONAL LOCKDOWN AND UNLOCK PERIOD OF COVID-19 PANDEMIC IN ASSAM
}

\author{
DR. SWAPNA DUTTA ${ }^{1}$, RUMI DUTTA ${ }^{2} \&$ SWAPNALI BORGOHAIN ${ }^{3}$ \\ ${ }^{1}$ Associate Professor, Departmen of Home Science, L.T.K. College, Azad, North Lakhimpur, Assam, India \\ ${ }^{2}$ Associate Professor, Departmen of Economics, L.T.K. College, Azad, North Lakhimpur, Assam, India \\ ${ }^{3}$ Assistant Professor, Departmen of Mathematics, L.T.K. College, Azad, North Lakhimpur, Assam, India
}

\section{ABSTRACT}

Covid-19 is a major health issue and challenges in the present time. This infectious disease caused by a new virus known as Corona virus. The most recently discovered corona virus is global epidemic of infectious disease. Therefore from the beginning of the outbreak appropriate efforts has been taken by the Government of India to prevent the spread of the virus. From $24^{\text {th }}$ March, 2020 the government of India has declared the national lockdown. As a result, all educational institution is closed in the country. This made an adverse effect in academic continuity of the college going students. UGC, the apex body of the Higher Education Institutions directed to the academic institutions to teach the students through online during this national lock down and unlocked days due to COVID-19. The present study aimed to know the attitude and academic engagement of the college students during the national lock down and unlocked days. The survey was carried out through online created in goggle form. Those students who are studied in different colleges of Assam were the respondents for the study. The study shown that the majority of students were received online classes through What's up, Google Classroom, Video etc but most of them were fear and confused regarding this corona virus.

KEYWORDS: COVID-19, Corona Virus, Academic Engagement, UGC

Received: Feb 08, 2020; Accepted: Feb 28, 2020; Published: Nov 17, 2020; Paper Id.: IJMPERDFEB202085

\section{INTRODUCTION}

Covid-19 is a major health issue and challenges in the present time. This infectious disease caused by a new virus known as Corona virus. COVID-19, popularly known as Novel Corona Virus, is associated with the respiratory disorder in humans which has been declared as a global epidemic and pandemic in the first quarter of the year 2020 by the World Health Organization.

On $24^{\text {th }}$ March 2020, nationwide lockdown was declared by the government of India for 21 days, limiting the movement of 1.3 billion population of India as a preventive measure against the Covid-19 pandemic. (1). It was ordered after a 14- hour voluntary public curfew on $22^{\text {nd }}$ March, followed by enforcement of a series of regulations in the country's COVID-19 affected regions. (2),(3). The lockdown was placed when the number of confirmed positive corona virus cases in India was approximately 500. (1). Observers stated that the lockdown had slowed the growth rate of pandemic by $6^{\text {th }}$ April to a rate of doubling every 6 days(4) and by $18^{\text {th }}$ April, to a rate of doubling every eight days. (5). the total of four phases of lockdown was continued until $31^{\text {st }}$ May, 2020. From $1^{\text {st }}$ June the Unlock 1.0 was started and till the date it is remaining. It was announced that educational institutions will remain 
closed till $31^{\text {st }}$ August, 2020.

As per the latest data, there are currently more than 3 million people infected by the Novel Corona Virus in India and close to 58 thousand deaths reported from different parts of the country. The top states with maximum number of infected cases are Maharashtra followed Andhra Pradesh, Bihar, Assam, Gujarat etc. At first Assam was placed comfortably out the list of infected areas by huge margins, but recent events led to its rise to more than 1 lakh which is a point of concern. The mortality rate is controlled at less than 3\% right now, which is better than the mortality rate of the country, but the model of spread is slowly moving towards an exponential trend which can lead to massive loss of lives and infrastructure.

Looking this condition several educational measures have been taken by Assam government. The Assam government has directed the schools to provide students with course materials and short video lectures on topics in the syllabi through WhatsApp to prevent learning gaps during the closure of educational institutes. Even all the students of Higher Secondary first year of 2019-20 academic years have been promoted to second year without conducting any examination. The Assam government also directed private schools to waive 50 per cent of fees for the month of April. The schools have also been directed not to increase fees during lockdown and to pay teaching and non-teaching staff without a pay cut. The government also launched a local educational television channel Gyan Brikshya for classes I to XII, to cover the learning loss due to the COVID-19 pandemic and lockdown. The government is also going to waive all fees relating to admission and other categories like examinations, sports, registration, laboratory etc. for all students in all educational institutions under the Assam education board. On 29 June, the government has decided to change the academic calendar for the schools of the state from January-December to April-March. The decision has been taken in order to compensate the loss of academic days due to COVID-19 pendemic.

In this context, this study is carried out to know the attitude and academic engagement during these national lockdown and unlock period of Covid-19 pandemic.

\section{OBJECTIVES}

- $\quad$ To know the attitude of students towards Covid-19 pandemic.

- $\quad$ To understand the academic engagement of students during lockdown and unlock period.

\section{METHODOLOGY}

The main objectives of the study is to know the academic engagement of college going students during the national lockdown and unlock period of Covid-19. Descriptive research design was followed for the present study. Convenience sampling techniques was used in the study. For the present study the college going students of different institution in Assam has been taken as respondents who were got admission before the year 2020. Data was collected by using online questionnaire (Google form). A total 119 respondents participated in the survey. The collected data was analysed in frequency and percentage. 


\section{MAJOR FINDINGS}

\section{Background Information of Respondents:}

Table 1: Back ground information

\begin{tabular}{|c|c|c|c|}
\hline SI.No & Factors & Frequency & Percentage \\
\hline \multirow{5}{*}{1} & Age & & \\
\hline & $18-20$ & 32 & $27 \%$ \\
\hline & $21-24$ & 14 & $62 \%$ \\
\hline & $24-26$ & & $11 \%$ \\
\hline & Gender & 55 & \\
\hline \multirow[t]{3}{*}{2} & Male & $\begin{array}{l}53 \\
64\end{array}$ & $46.2 \%$ \\
\hline & Female & & $53.8 \%$ \\
\hline & Types of locality & & \\
\hline \multirow[t]{3}{*}{3} & Urban & 27 & \\
\hline & Semi Urban & 53 & $22.7 \%$ \\
\hline & Rural & 39 & $32.8 \%$ \\
\hline \multirow[t]{5}{*}{4} & Course of study & 28 & \\
\hline & Higher secondary & 74 & $24 \%$ \\
\hline & UG & 11 & $62 \%$ \\
\hline & PG & 6 & $\begin{array}{l}9 \% \\
50\end{array}$ \\
\hline & Аाпу Uात्र & & \\
\hline
\end{tabular}

The above table shows that $27 \%$ of respondents belonged to $18-20$ age group, $62 \%$ respondents belonged to $21-24$ age group and 11\% respondents belonged to 24-26 age group. Among them $46.2 \%$ are male and 53.8\% are female students. $22.7 \%$ respondents belonged to urban area, $44.5 \%$ belonged to semi urban area and $32.8 \%$ respondents were from rural area. It has been seen that $24 \%$ of respondents are perusing higher secondary course, $62 \%$ respondents are pursuing UG course, $9 \%$ of them are pursuing post graduate course and another $5 \%$ of them pursuing their study in B.Ed and diploma course etc.

\section{DATA RELATED TO COVID -19}

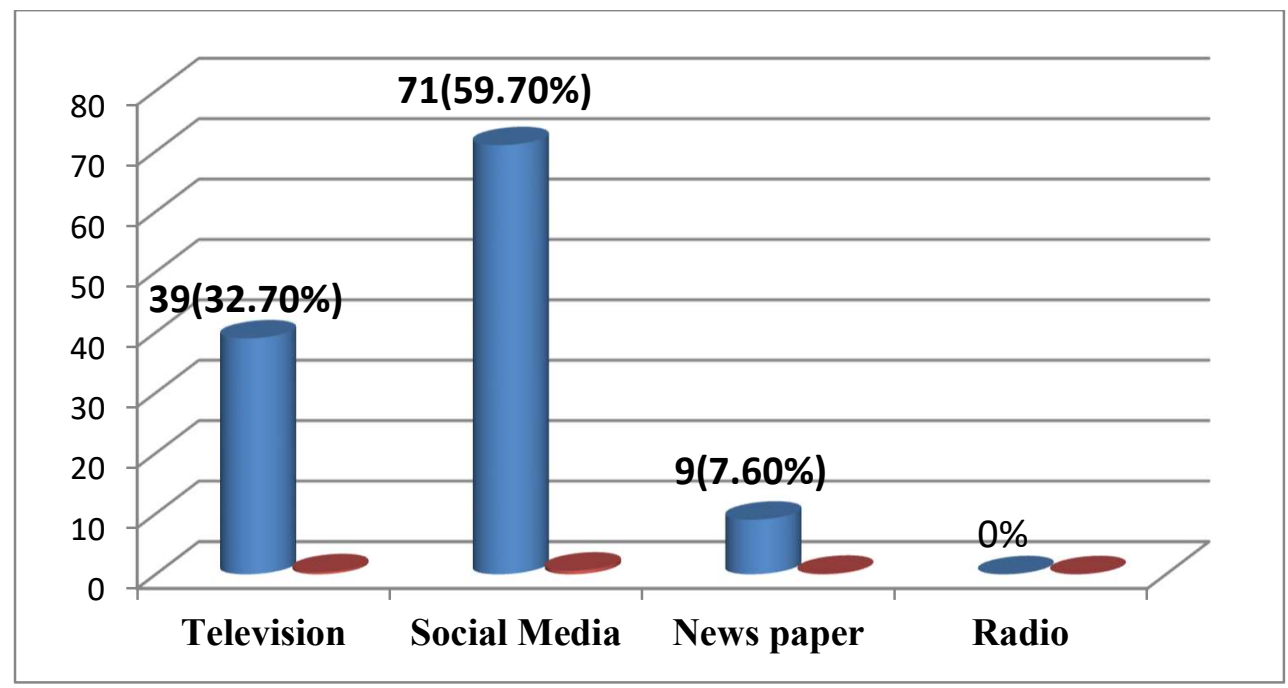

Figure 1: Sources of Information on COVID-19 Updates 
From the above table it has been seen that majority of respondents (59.70\%) were getting information about Covid-19 pandemic from different social media. 32.7\% of them were getting information from Television while only $7.6 \%$ of respondents were getting information regarding Covid-19 pandemic from Newspaper. It has been inferred that respondents were collected data and update about pandemic through social media especially through what'sapp, facebook etc.

\section{FEELINGS OF RESPONDENTS ABOUT COVID-19}

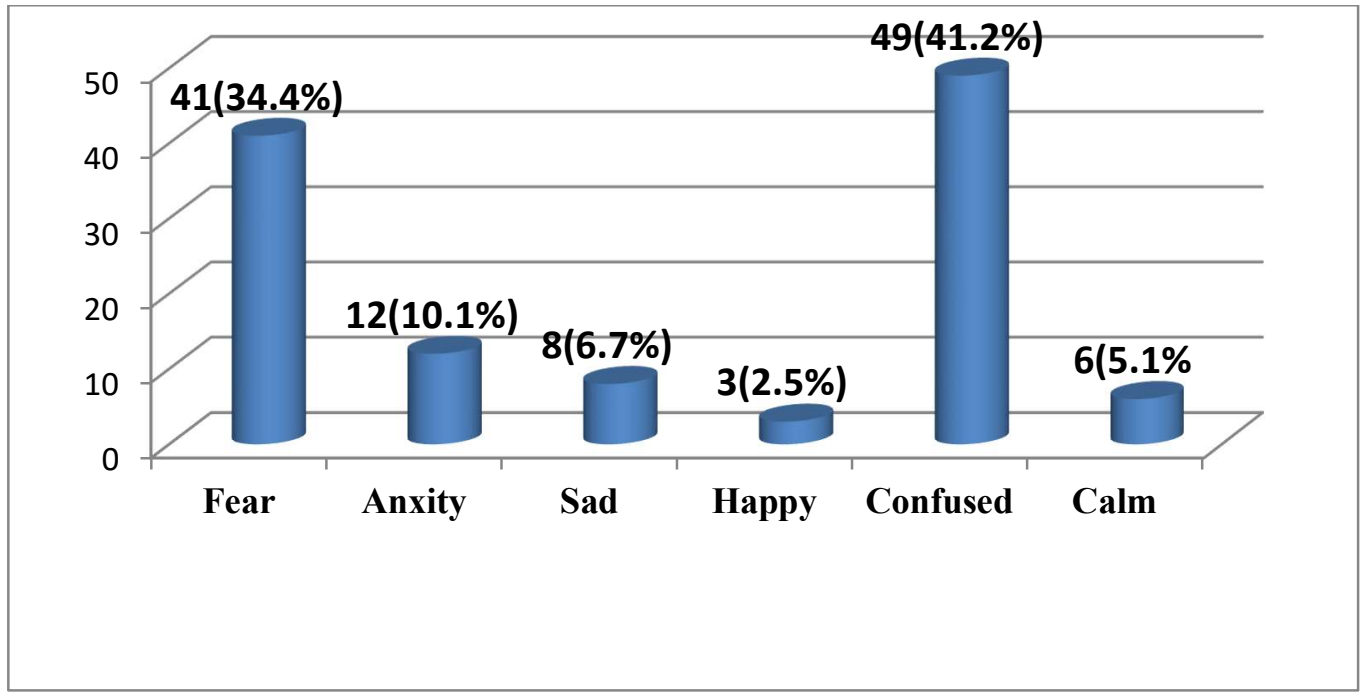

Figure 2

The above graph shows that majority of the respondents $(41.2 \%)$ presently feel Confused, $34.5 \%$ feel fear, and $10.1 \%$ presently feel anxious, Very minimal number of respondents reported that they feel happy and calm. From this it can be said that the disease COVID-19 pandemic has impact on psychological wellness of respondents.

\section{RECEIVED ONLINE TEACHING FROM THE COLLEGE}

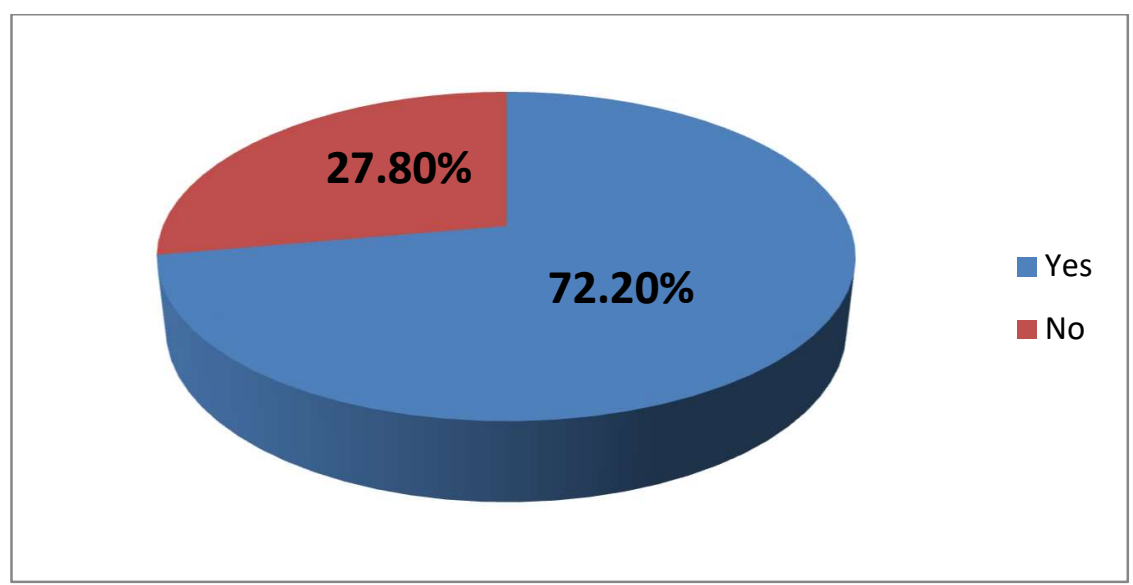

Figure 3

The above graph shows that majority of the respondents $(72.2 \%)$ have received online teaching from their respective institution during this lockdown and unlock period and the rest $(27.8 \%)$ of the respondents reported that they are not able to get online teaching. 


\section{IF YES, HOW CAN RESPONDENTS GET}

\section{$15.20 \%$}

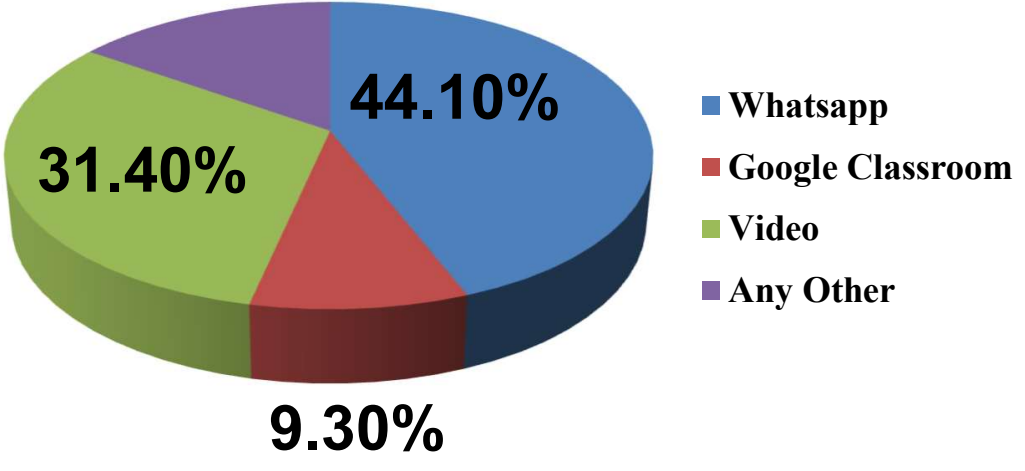

Figure 4

From the above table it has been seen that those who were able to get online teaching from their teacher, the majority of the respondents (44.1\%) uses Whatsapp group as online platform for academic engagement, 9.3\% uses Google classroom as online platform for academic engagement, 31.4\% uses video online platform for academic engagement, $15.2 \%$ of the respondents attended live classes through Zoom, Google class meet for their academic engagement. They have opined that these kinds of online platforms were created by their institution for academic engagement of students.

\section{DO RESPONDENTS RECEIVE ASSIGNMENT/ PROJECT FROM THE TEACHER?}

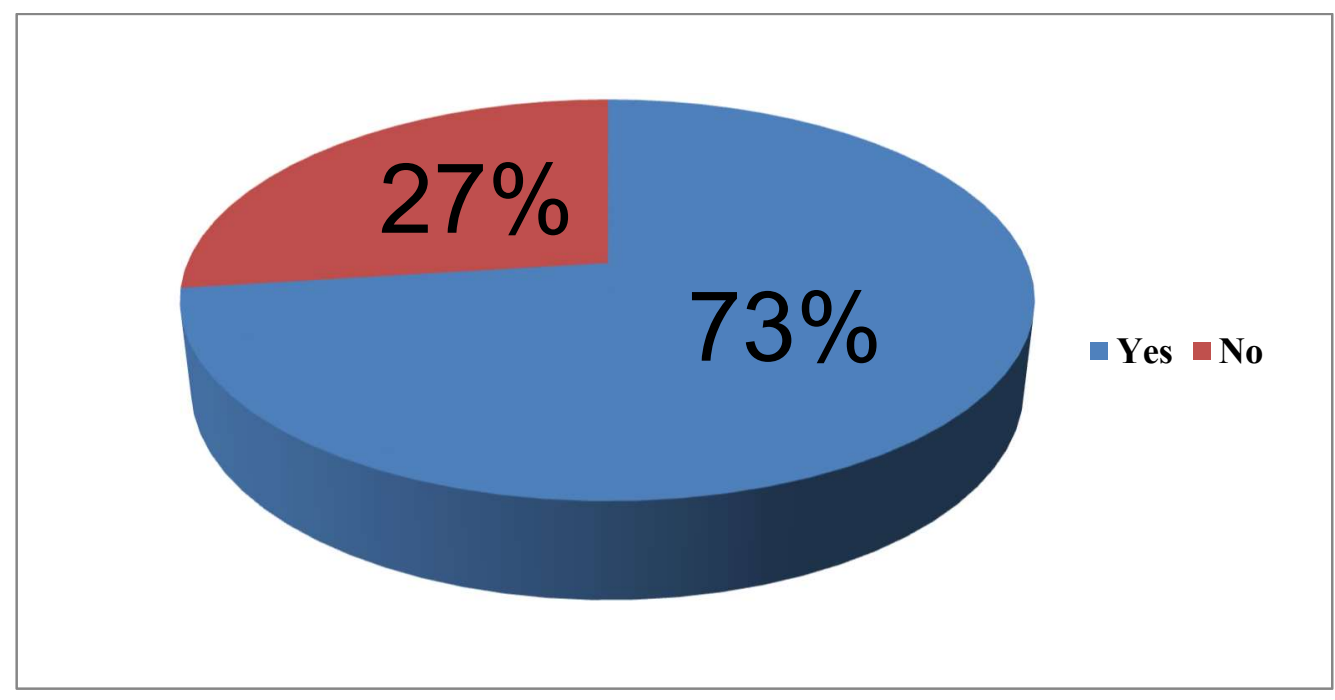

Figure 5

The above graph shows that majority of the respondents $(73 \%)$ reported that the teachers were sharing their academic inputs with their students, $27 \%$ of respondents reported that they were not able to get any academic inputs from their teacher. 
DO THE TEACHER SHOWING INTEREST IN FOLLOW UP WITH THESE ACADEMIC INPUTS SHARING BY THEM

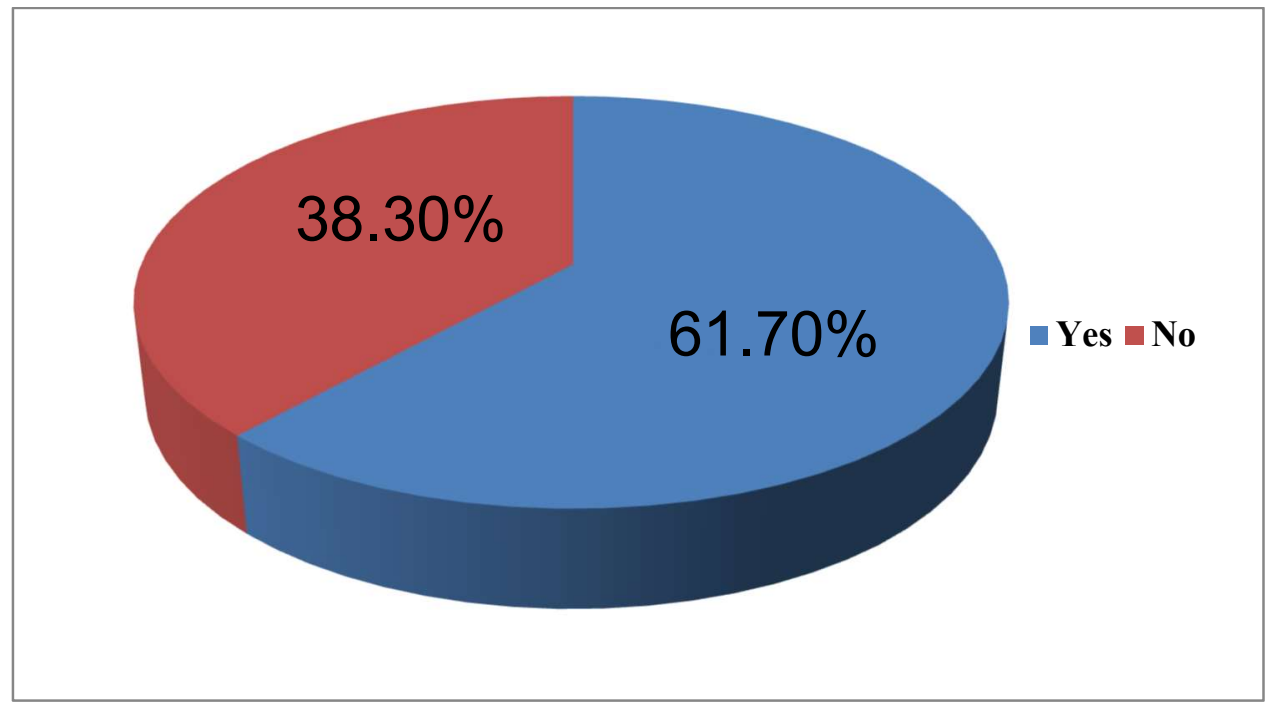

Figure 6

From the above given graph it can be inferred that $61.7 \%$ of teacher are regularly contact with regards to these assignments while $38.3 \%$ of teacher are not are not showing interest to the academic inputs shared by them.

\section{DO YOU INVOLVE IN ANY ONLINE COURSE PROVIDED BY GOVERNMENT}

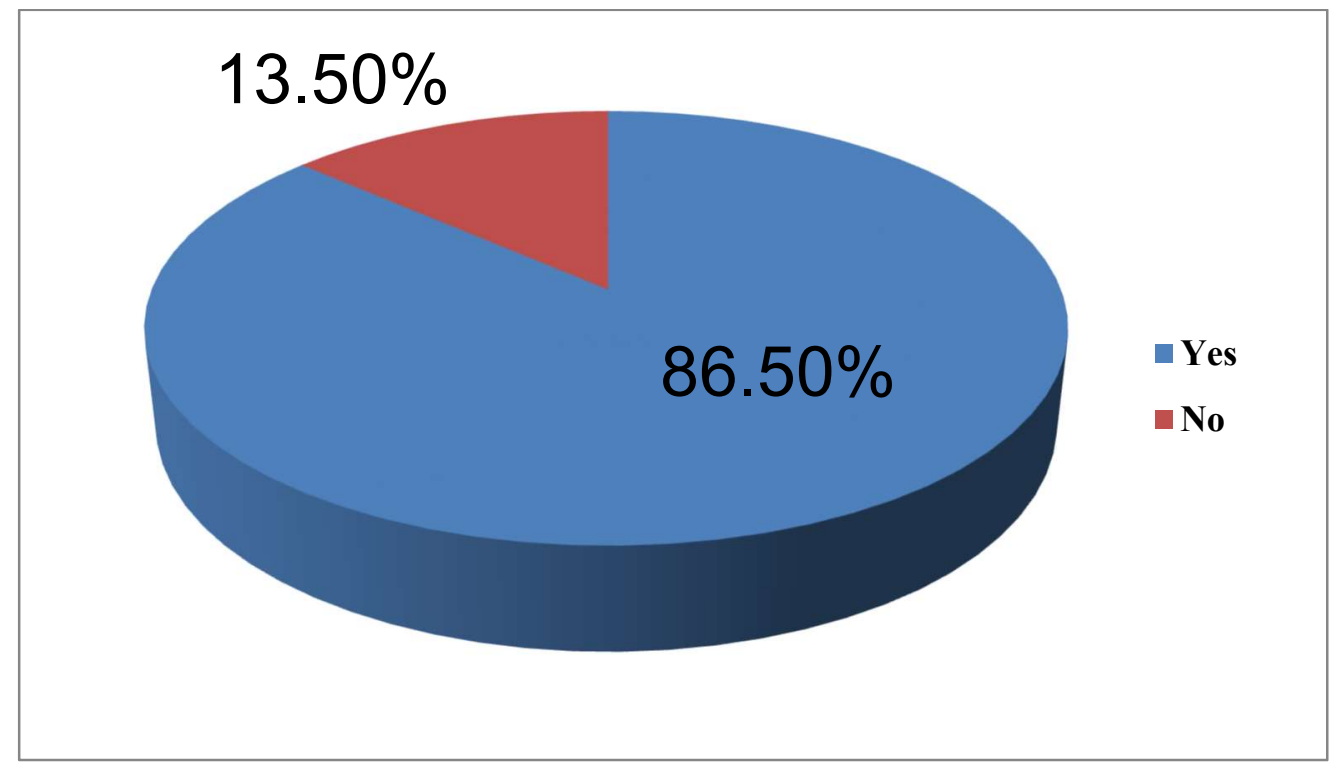

Figure 7

The study found out that majority of the respondents $(86.5 \%)$ has not enrolled in any of the online courses provided by Government. Only 13.5\% students have enrolled in some online courses which were provided by Government. 


\section{IF YES, FROM WHERE YOU GET THESE COURSE}

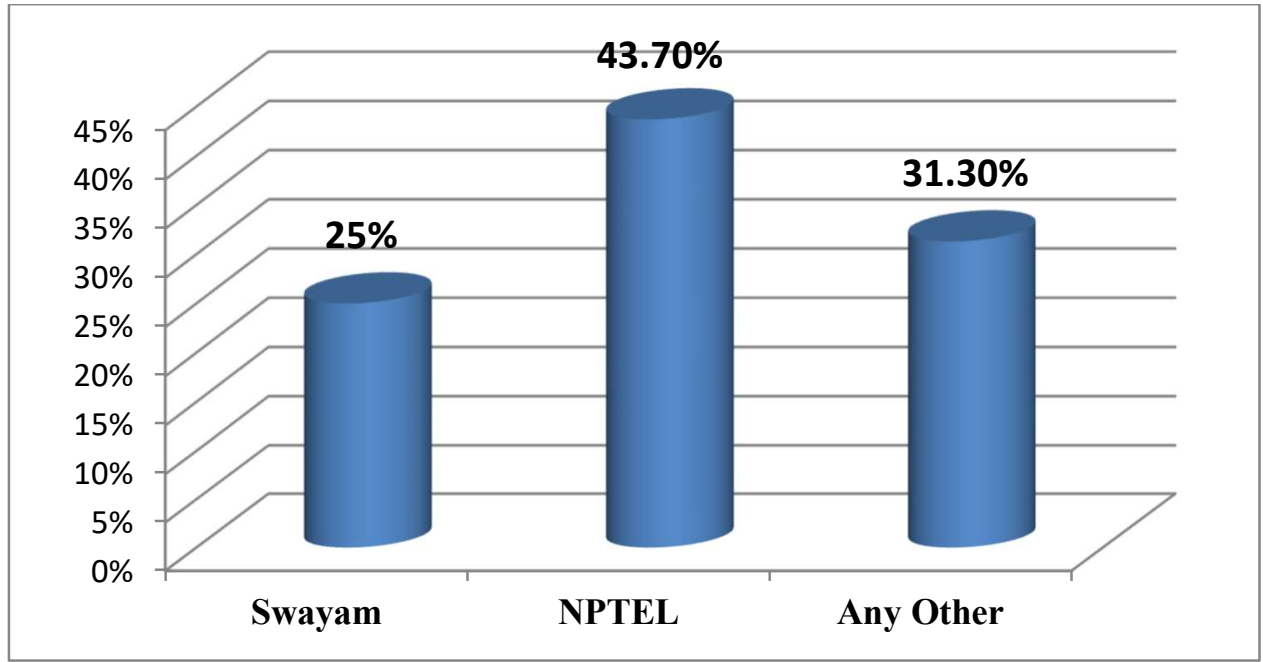

Figure 8

The study shows that majority of respondents have not joined for any kind of online courses provided by government. Only 16 respondents were engaged themselves in online courses provided by Government. Among 16 (13.5\%) of respondents 4(25) \% have joined online courses in Swayam platform of UGC, Seven (43.7\%) have joined NPTEL and rest three (31.3\%) has joined in other platforms like Diksha, Gyan Brikshya etc for their online courses.

\section{PROBLEMS FACED BY RESPONDENTS IN ONLINE TEACHING AND LEARNING}

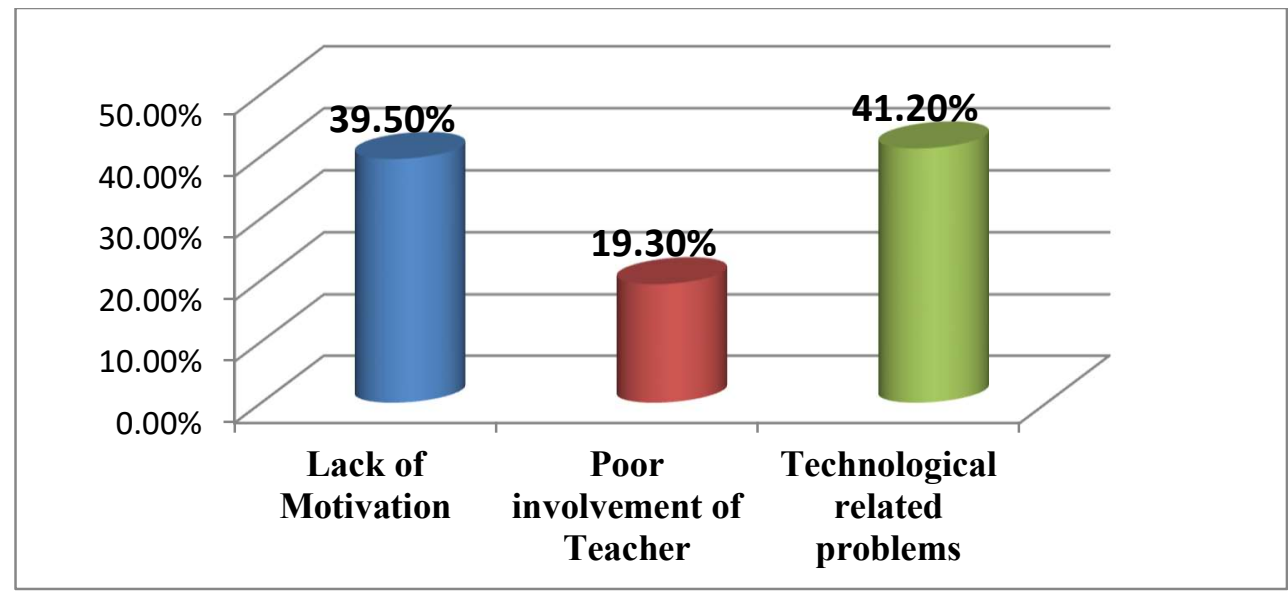

Figure 9

From the study it was found out that $39.5 \%$ of the respondents faced lack of motivation that causes poor academic engagement, $19.3 \%$ of the respondents said poor involvement of teachers with them, $41.2 \%$ faced technology related issues has resulted in poor academic engagement.

\section{WHETHER ONLINE TEACHING AND LEARNING ARE EFFECTIVE}

Respondents were asked about the online teaching and learning whether it is effective or not. The following diagram shows the attitude of the respondents towards online teaching and learning. 


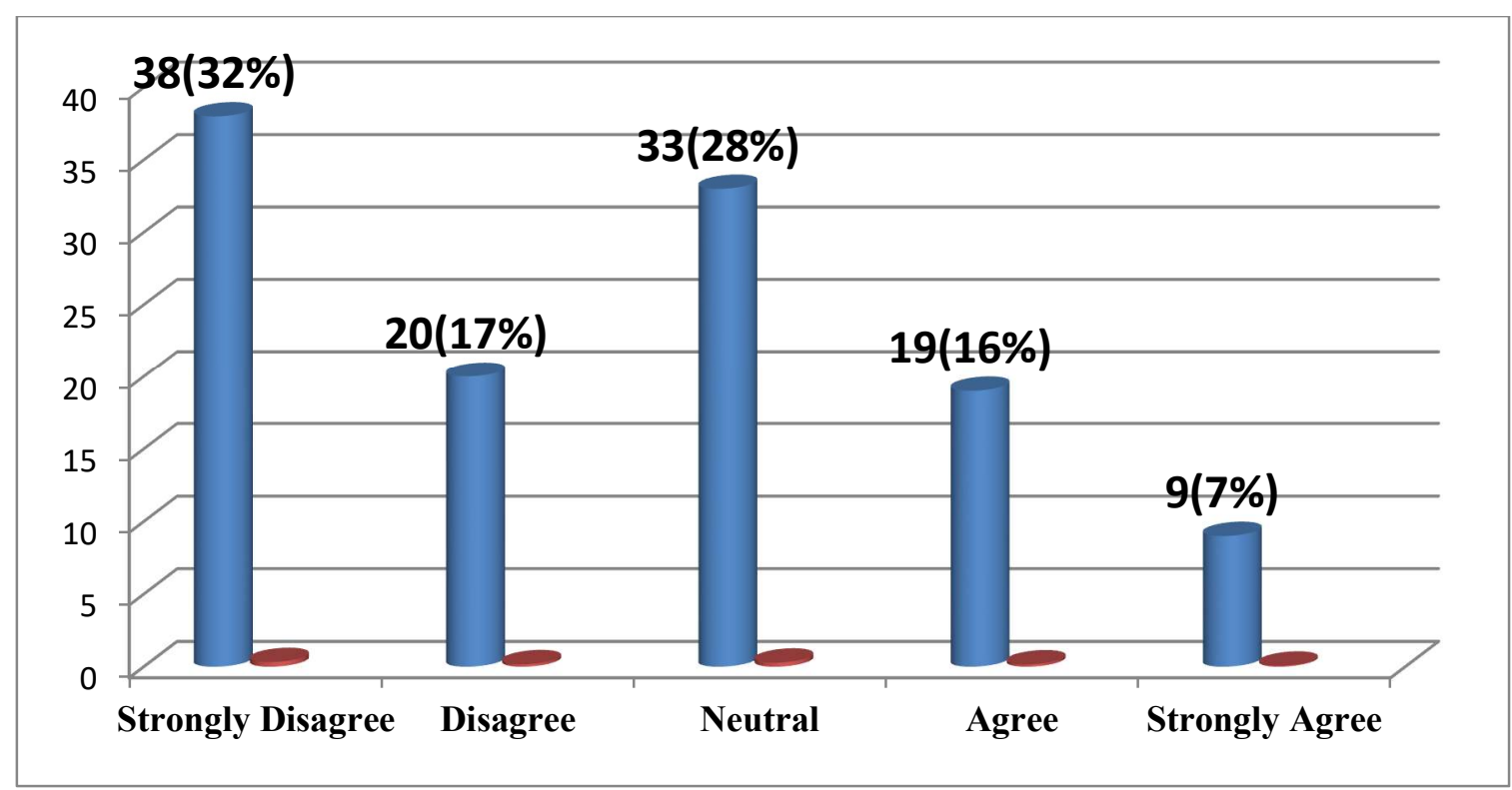

Figure 10

The above diagram shows that $32 \%$ of respondents were strongly disagree towards online teaching and learning whereas only $7 \%$ respondents were strongly agree towards this. Another $17 \%$ of respondents were just disagreeing and $16 \%$ of respondents were agreeing regarding online teaching and learning. $28 \%$ of respondents were in neutral position.

\section{VIEWS AND SUGGESTIONS PROVIDED BY RESPONDENTS}

- Both online and offline study is required.

- The timetable and rules of online teaching and learning should be disciplined and strict.

- Live classes are better than online classes. Sitting in front of any electronic device for hours is not good for eyes as well as for health and moreover it feels lethargic and bored at some point. Whereas during live classes interaction with teachers are better and more efficient and students remain alert all the time.

- $\quad$ To make teaching learning more fruitful and effective both digital and physical classroom teachings necessary.

- Technology adaptation in the field of education should be improved.

\section{CONCLUSIONS}

Since the nation is undergoing a difficult situation due to COVID-19 pandemic, it is very important to follow the directions of the Government. The joined efforts of all the citizen of the nation can play a vital role in addressing the issue. The national lockdown period can be effectively utilized for the academic enrichment of the students and faculty members. The positive initiatives from the students and faculty side can create positive impact in the academic scenario of the nation. This is the right time to utilize and experiment modern technology in the field of education and communication.

\section{REFERENCES}

1. "Coronavirus disease named Covid-19". BBC News Online. 11 February 2020. Archived from the original on 15 February 2020. Retrieved 15 February 2020.

2. Sheikh, Knvul; Rabin, Roni Caryn (10 March 2020). "The Coronavirus: What Scientists Have Learned So Far". The New York Times. Retrieved 24 March 2020. 
3. Satananda Bhattacharjee (1 April 2020). "1st coronavirus case in Assam". The Telegraph. Archived from the original on 3 April 2020. Retrieved 22 April 2020.

4. "Covid-19 Dashboard Assam". The Government of Assam. Retrieved 29 August 2020.

5. Utpal Parashar (29 June 2020). "Assam extends academic calendar from December to March due to Covid-19". Hindustan Times. Retrieved 30 June 2020.

6. $\quad$ "Assam changes school calendar to Apr-Mar from Jan-Dec". Republic. 29 June 2020. Retrieved 30 June 2020. 

